\title{
Outcomes of leader empowering behaviour in a retail organisation
}

\begin{tabular}{|c|c|}
\hline \multicolumn{2}{|c|}{$\begin{array}{l}\text { Authors: } \\
\text { Kleinjan Redelinghuys }{ }^{1} \text { (I) } \\
\text { Sebastiaan Rothmann }{ }^{2} \\
\text { Elrie Botha }^{2}\end{array}$} \\
\hline \multicolumn{2}{|c|}{$\begin{array}{l}\text { Affiliations: } \\
\text { }{ }^{1} \text { Department of Industrial } \\
\text { Psychology and People } \\
\text { Management, University of } \\
\text { Johannesburg, Johannesburg, } \\
\text { South Africa }\end{array}$} \\
\hline \multicolumn{2}{|c|}{$\begin{array}{l}{ }^{2} \text { Optentia Research Focus } \\
\text { Area, North-West University, } \\
\text { Vanderbijlpark, South Africa }\end{array}$} \\
\hline \multicolumn{2}{|c|}{$\begin{array}{l}\text { Corresponding author: } \\
\text { Kleinjan Redelinghuys, } \\
\text { 21887217@nwu.ac.za }\end{array}$} \\
\hline $\begin{array}{l}\text { Dates: } \\
\text { Received: } 04 \wedge \\
\text { Accepted: } 06 \\
\text { Published: } 23\end{array}$ & $\begin{array}{l}\text { Jov. } 2019 \\
\text { Aug. } 2020 \\
\text { Oct. } 2020\end{array}$ \\
\hline \multicolumn{2}{|c|}{$\begin{array}{l}\text { How to cite this article: } \\
\text { Redelinghuys, K., Rothmann, } \\
\text { S., \& Botha, E. (2020). } \\
\text { Outcomes of leader } \\
\text { empowering behaviour in a } \\
\text { retail organisation. South } \\
\text { African Journal of Business } \\
\text { Management, 51(1), a1837. } \\
\text { https://doi.org/10.4102/ } \\
\text { sajbm.v51i1.1837 }\end{array}$} \\
\hline \multicolumn{2}{|c|}{$\begin{array}{l}\text { Copyright: } \\
\text { (c) 2020. The Authors. } \\
\text { Licensee: AOSIS. This wo } \\
\text { is licensed under the } \\
\text { Creative Commons } \\
\text { Attribution License. }\end{array}$} \\
\hline \multicolumn{2}{|l|}{ Read online: } \\
\hline 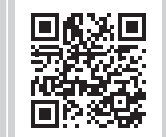 & $\begin{array}{l}\text { Scan this QR } \\
\text { code with your } \\
\text { smart phone or } \\
\text { mobile device } \\
\text { to read online. }\end{array}$ \\
\hline
\end{tabular}

Purpose: The aim of the study was to assess the associations leader empowering behaviour have with person-environment fit, job satisfaction and intention to leave.

Design/methodology/approach: A cross-sectional survey design was used with a sample $(N=398)$ of retail employees from Gauteng. The Leader Empowering Behaviour Questionnaire, Job Satisfaction Scale, Perceived Fit Scale and Turnover Intention Scale were administered. Structural equation modelling was performed to assess the study hypotheses.

Findings/results: Findings showed that leader empowering behaviour is positively associated with person-environment fit and job satisfaction, whereas it is negatively associated with the intention to leave.

Practical implications: When leaders share the right amount of power, information, decisionmaking authority and skills development opportunities with their employees; coach them well; and hold them accountable for controllable outcomes, it should enable them to establish a well-fitted, satisfied and committed workforce.

Originality/value: Studies assessing leader empowering behaviour as an antecedent of person-environment fit have been scarce.

Keywords: leader empowering behaviour; person-environment fit; job satisfaction; intention to leave; retail organisation.

\section{Introduction}

It is unreasonable for leaders to be 'know-it-alls' when it comes to strategic or operational decision-making authority (Lovelace, Manz, \& Alves, 2007). As a result, companies are increasingly focused on how their employees can alleviate the demands of their leaders and subsequently also increase the purpose, authority and importance employees derive from their work. Thus, to lead effectively, leaders need to adopt behaviours that are sensitive to the situation, needs and capabilities of their employees (Anderson, Baur, Griffith, \& Buckley, 2017). One leadership approach that actively fosters employee participation is leader empowering behaviour.

\section{Leader empowering behaviour}

Although discrepancies occur regarding the components that constitute empowering leadership behaviours (Ahearne, Mathieu, \& Rapp, 2005; Amundsen \& Martinsen, 2014; Arnold, Arad, Rhoades, \& Drasgow, 2000; Konczak, Stelly, \& Trusty, 2000), studies generally concur that it sufficiently differs from other leadership constructs (Cheong, Yammarino, Dionne, Spain, \& Tsai, 2019; Sharma \& Kirkman, 2015). This confirms the scholarly relevance of leader empowering behaviour.

Konczak et al. (2000) conceptualised leader empowering behaviour according to six dimensions: delegation of authority, accountability, self-directed decision-making, skills development, coaching for innovative performance and information sharing. Thus, leaders who display this type of behaviour offer their followers a larger chunk of authority, responsibility and independence. Through knowledge sharing and the prioritisation of skills development, employees are sufficiently coached, novelty is encouraged and failures are regarded as building blocks (Konczak et al., 2000). When leaders empower their employees in a manner that satisfies their desire to be empowered, positive outcomes generally ensue (Lee, Cheong, Kim, \& Yun, 2017). 


\section{Outcomes of leader empowering behaviour}

Associations between leader empowering behaviour, person-environment fit, job satisfaction and intention to leave have been studied before. Redelinghuys and Botha (2016) found that person-environment fit indirectly affected the intention to leave via job satisfaction. Additionally, they established that leader empowering behaviour moderated the relationship between person-environment fit, job satisfaction and intention to leave. They, however, did not consider the potential direct impact leader empowering behaviour may have on the study outcomes. Therefore, the aim of the study was to assess the associations leader empowering behaviour have with person-environment fit, job satisfaction and intention to leave.

Person-environment fit refers to the degree to which individual characteristics (needs, abilities, values) are in line with environmental characteristics (supplies, demands, values) (Kristof-Brown \& Guay, 2011). When employees experience a good fit with their work environment, their values correspond to those of the organisation (person-organisation fit), their needs are sufficiently addressed by the organisation's reward structure (needs-supplies fit), and they have the necessary capabilities to deal with the demands of their job (demandsabilities fit) (Cable \& DeRue, 2002).

Leaders play a pivotal role in employees' work experiences (Tuckey, Bakker, \& Dollard, 2012), where perceived good leadership usually equates to positive outcomes. Although studies assessing leader empowering behaviour as an antecedent of person-environment fit have been scarce, there is some evidence to suggest a positive association between the constructs (Cai, Cai, Sun, \& Ma, 2018). In their study, Cai et al. (2018) established that leader empowering behaviour is significantly associated with person-job fit (consisting of demands-abilities fit and needs-supplies fit). Even though they assessed person-environment fit from a multidimensional perspective (person-job fit and persongroup fit), they excluded person-organisation fit. In line with Cable and DeRue's (2002) three-dimensional personenvironment fit conceptualisation, we included personorganisation fit and differentiated between demands-abilities fit and needs-supplies fit. Therefore, the following hypothesis is posited:

H1: Leader empowering behaviour is positively associated with person-environment fit.

Job satisfaction refers to the general satisfaction an employee has with his or her job (Spector, 1997). Numerous studies suggest a positive association between leader empowering behaviour and job satisfaction (Amundsen \& Martinsen, 2014; Konczak et al., 2000; Vecchio, Justin, \& Pearce, 2010). A meta-analytic study (Kim, Beehr, \& Prewett, 2018) has also confirmed these findings. Thus, employees should be more satisfied in work environments where their leaders exhibit empowering behaviours such as involvement in decisionmaking, skills improvement opportunities, coaching and knowledge sharing. Therefore, the following hypothesis is posited:

H2: Leader empowering behaviour is positively associated with job satisfaction.

Lastly, by creating a favourable work environment for employees, leaders may reduce the need for employees to explore alternative job opportunities. Intention to leave refers to the relative strength of an employee's intention to seek employment opportunities elsewhere (Hom \& Griffeth, 1991). The role superiors play in employees' decisions to remain or depart from organisations is well supported empirically (Kiazad, Holtom, Hom, \& Newman, 2015; Taplin \& Winterton, 2007) and reflects the words of Buckingham and Coffman (1999, p. 32): 'People leave managers, not companies'. In line with social exchange theory (Blau, 1964; Cropanzano \& Mitchell, 2005), employees generally respond positively towards an entity (e.g. team, organisation, supervisor) that beneficially impacts them. Amongst others, these positive employee responses may entail organisational commitment (Settoon, Bennett, \& Liden, 1996), which is indicative of an employee's decision to remain with an organisation. The negative association between leader empowering behaviour and intention to leave has been confirmed by previous studies (Bester, Stander, \& Van Zyl, 2015; Van Schalkwyk, Du Toit, Bothma, \& Rothmann, 2010). A meta-analytic study (Kim et al., 2018) has also confirmed a relationship between leader empowering behaviour and withdrawal behaviour (e.g. intention to leave). Therefore, the following hypothesis is posited:

H3: Leader empowering behaviour is negatively associated with intention to leave.

\section{Method}

\section{A cross-sectional survey design was used with a convenience sample of retail employees}

\section{Participants}

A total of 398 participants were sampled from a retail organisation in the Gauteng Province. As per Table 1, the

\begin{tabular}{llcc} 
TABLE 1: Participant characteristics $(N=398)$. & & \\
\hline Item & Category & Frequency & \% \\
\hline Gender & Male & 125 & 31.4 \\
& Female & 273 & 68.6 \\
Race & Black people & 231 & 58 \\
& Mixed race people & 20 & 5 \\
& Indian people & 13 & 3.3 \\
& White people & 132 & 33.2 \\
& Other & 1 & 0.3 \\
& Missing values & 1 & 0.3 \\
Highest educational level & Matric & 242 & 60.8 \\
& Diploma & 88 & 22.1 \\
& Degree & 15 & 3.8 \\
& Postgraduate degree & 14 & 3.5 \\
& Technical qualification & 22 & 5.5 \\
& Missing values & 17 & 4.3 \\
\hline
\end{tabular}


majority of participants were black people (58\%), who were female $(68.6 \%)$, with a matric certificate $(60.8 \%)$ as their highest educational level.

\section{Measuring instruments}

The Leader Empowering Behaviour Questionnaire (LEBQ; Konczak et al., 2000) assessed the leader empowering behaviour. The scale comprises 19 questions rated on a seven-point response scale, ranging from 1 (strongly disagree) to 7 (strongly agree). Five of the six subscales were measured by three questions: delegation of authority (e.g. 'My manager gives me the authority to make changes necessary to improve things'), accountability (e.g. 'I am held accountable for performance and results'), selfdirected decision making (e.g. 'My manager relies on me to make my own decisions about issues that affect how work gets done'), skills development (e.g. 'My manager ensures that continuous learning and skill development are priorities in our department') and coaching for innovative performance (e.g. 'My manager focuses on corrective action rather than placing blame when I make a mistake'). Information sharing was measured by four questions: (e.g. 'My manager provides me with the information I need to meet customers' needs'). The scale has yielded reliable and valid findings in South African contexts (Bester et al., 2015)

The Perceived Fit Scale (PFS; Cable \& DeRue, 2002) assessed the person-environment fit. The scale comprises nine questions rated on a seven-point response scale, ranging from 1 (strongly disagree) to 7 (strongly agree). All three subscales include three questions: person-organisation fit (e.g. 'My organisation's values and culture provide a good fit with the things that I value in life'), demands-abilities fit (e.g. 'My personal abilities and education provide a good match with the demands that my job places on $\mathrm{me}^{\prime}$ ) and needs-supplies fit (e.g. 'The job that I currently hold gives me just about everything that I want from a job'). The scale's three-factor structure and reliability is well established in the South African context (Redelinghuys, Rothmann, \& Botha, 2019a).

The Job Satisfaction Scale (JSS; Hellgren, Sjöberg, \& Sverke, 1997) assessed the job satisfaction. The scale comprises three questions rated on a five-point response scale, ranging from 1 (disagree) to 5 (agree). Covering a solitary dimension, a sample item includes: 'I am content with my job'. The scale has yielded reliable and valid findings in South African contexts (Smit, De Beer, \& Pienaar, 2016).

The Turnover Intentions Scale (TIS; Sjöberg \& Sverke, 2000) assessed the intention to leave. The scale comprises three questions rated on a five-point response scale, ranging from 1 (strongly disagree) to 5 (strongly agree). Covering a single dimension, a sample item includes: 'If I was completely free to choose, I would leave this job'. The scale has yielded reliable and valid findings in South African contexts (Redelinghuys, Rothmann, \& Botha, 2019b).

\section{Research procedure}

Study permission was granted by the retail organisation's management team and the North-West University's ethical committee. Participants had the opportunity to voluntarily complete the questionnaires in the comfort of their own workspace. The study was sufficiently introduced and explained by an information letter accompanying the questionnaires. Participants had ample opportunities to ask questions pertaining to the study.

\section{Statistical analysis}

Mplus 8.2 (Muthén \& Muthén, 1998-2019) and SPSS25 (IBM Corp, 2017) were chosen as the preferred statistical software. Structural equation modelling was used to assess the study hypotheses. The following fit indices in Mplus were used to assess the suitability of the models: the Chi-square value, the standardised root mean square residual (SRMR), the root mean square error of approximation (RMSEA), Tucker-Lewis Index (TLI), comparative fit index (CFI), Akaike information criterion (AIC) and the Bayesian information criterion (BIC). On all the indices, lower values indicate better fit, except for the CFI and TLI, where higher values indicate better fit (Wang \& Wang, 2012).

\section{Ethical consideration}

The study received ethical clearance from Optentia Ethics Committee, North-West University. Ethical clearance number: OPT-2014-001.

\section{Results}

\section{Descriptive statistics, Raykov's rho values and correlations}

Table 2 reports the descriptive statistics, Raykov's rho values and correlation coefficients of the measuring battery.

Sufficient Raykov's (2009) rho values were found for each scale $(>0.70)$. All variables were practically and statistically significantly related to each other to varying degrees.

\section{Measurement model testing}

To assess the factor structures of the constructs under scrutiny, confirmatory factor analyses via Mplus was conducted. An initial measurement model (Model 1) was

TABLE 2: Descriptive statistics, Raykov's rho values and correlation coefficients.

\begin{tabular}{lcccccc}
\hline Variable & $\mathbf{M}$ & SD & $\boldsymbol{\rho}$ & $\mathbf{1}$ & $\mathbf{2}$ & $\mathbf{3}$ \\
\hline 1. Leader empowering behaviour & 4.49 & 1.37 & 0.97 & - & - & - \\
2. Person-environment fit & 4.65 & 1.32 & 0.95 & 0.69 & - & - \\
3. Job satisfaction & 3.78 & 1.22 & 0.90 & 0.65 & 0.77 & - \\
4. Intention to leave & 2.91 & 1.27 & 0.90 & -0.49 & -0.64 & -0.66 \\
\hline
\end{tabular}

M, mean; SD, standard deviation. 
TABLE 3: Goodness-of-fit statistics of competing measurement models.

\begin{tabular}{|c|c|c|c|c|c|c|c|c|c|}
\hline \multirow[t]{2}{*}{ Model } & \multirow[t]{2}{*}{$\chi^{2}$} & \multirow[t]{2}{*}{$d f$} & \multirow[t]{2}{*}{ TLI } & \multirow[t]{2}{*}{ CFI } & \multicolumn{2}{|c|}{ RMSEA } & \multirow[t]{2}{*}{ SRMR } & \multirow[t]{2}{*}{ AIC } & \multirow[t]{2}{*}{ BIC } \\
\hline & & & & & Estimate & $90 \% \mathrm{Cl}$ & & & \\
\hline 1 & 891.542 & 512 & 0.94 & 0.95 & 0.04 & {$\left[\begin{array}{lll}0.04 & 0.05\end{array}\right]$} & 0.05 & 44325.15 & 44791.56 \\
\hline 2 & 1002.912 & 513 & 0.92 & 0.93 & 0.05 & {$\left[\begin{array}{llll}0.04 & 0.05\end{array}\right]$} & 0.05 & 44478.44 & 44940.87 \\
\hline 3 & 1565.871 & 518 & 0.84 & 0.85 & 0.07 & {$\left[\begin{array}{llll}0.07 & 0.08\end{array}\right]$} & 0.06 & 45261.53 & 45704.03 \\
\hline 4 & 1212.619 & 515 & 0.89 & 0.90 & 0.06 & {$\left[\begin{array}{ll}0.05 & 0.06\end{array}\right]$} & 0.06 & 44763.33 & 45217.79 \\
\hline
\end{tabular}

$\chi^{2}$, Chi-square statistic; $d f$, degrees of freedom; AIC, Akaike information criterion; BIC, Bayes information criterion; CFI, comparative fit index; RMSEA, root mean square error of approximation; SRMR, standardised root mean square residual; TLI, Tucker-Lewis index.

specified and evaluated against alternative models (Models 2-4) to establish the best-fitting model.

Model 1 comprised two second-order factors: leader empowering behaviour and person-environment fit and two first-order factors: job satisfaction and intention to leave (each measured by three observed variables). Leader empowering behaviour comprised six factors: delegation of authority, accountability, self-directed decision-making, information sharing, skills development and coaching for innovative performance. Each factor was measured by three observed variables, except for information sharing (measured by four observed variables). Person-environment fit comprised three factors: person-organisation fit, demands-abilities fit and needs-supplies fit (each measured by three observed variables).

Competing measurement models were also tested. In Model 2, person-environment fit comprised two factors: person-organisation fit (measured by three observed variables) and person-job fit (needs-supplies and demands-abilities fit) (measured by six observed variables). In Model 3, leader empowering behaviour comprised one factor (measured by 19 observed variables). In Model 4, person-environment fit comprised one factor (measured by nine observed variables).

The original measurement model yielded a $\chi^{2}$ of 891.542 $(d f=512)$. The CFI (0.95), TLI (0.94), RMSEA (0.04), $\chi^{2} / d f(1.74)$ and SRMR values (0.05) were all acceptable. The AIC and BIC values of the initial measurement model were also the lowest. Results are indicated in Table 3.

\section{Structural model testing}

A structural model (Model 5) was specified and tested in line with the best fitting measurement model (Model 1). No difference in fit values between Model 1 and Model 5 were found, indicating adequate model specification. Model 5 produced the following fit statistics: $\chi^{2}=891.542$; $d f=512 ; p<0.001 ; \mathrm{TLI}=0.95 ; \mathrm{CFI}=0.94 ; \mathrm{RMSEA}=0.04$ $(90 \%$ CI 0.060, 0.065); SRMR $=0.05 ; \mathrm{AIC}=44325.15 ; \mathrm{BIC}=$ 44791.56

Figure 1 illustrates the standard path coefficients found with leader empowering behaviour as independent variable and person-environment fit, job satisfaction and intention to leave as dependent variables.

For the model portion focusing on person-environment fit, leader empowering behaviour's path coefficient $(\beta=0.69$;

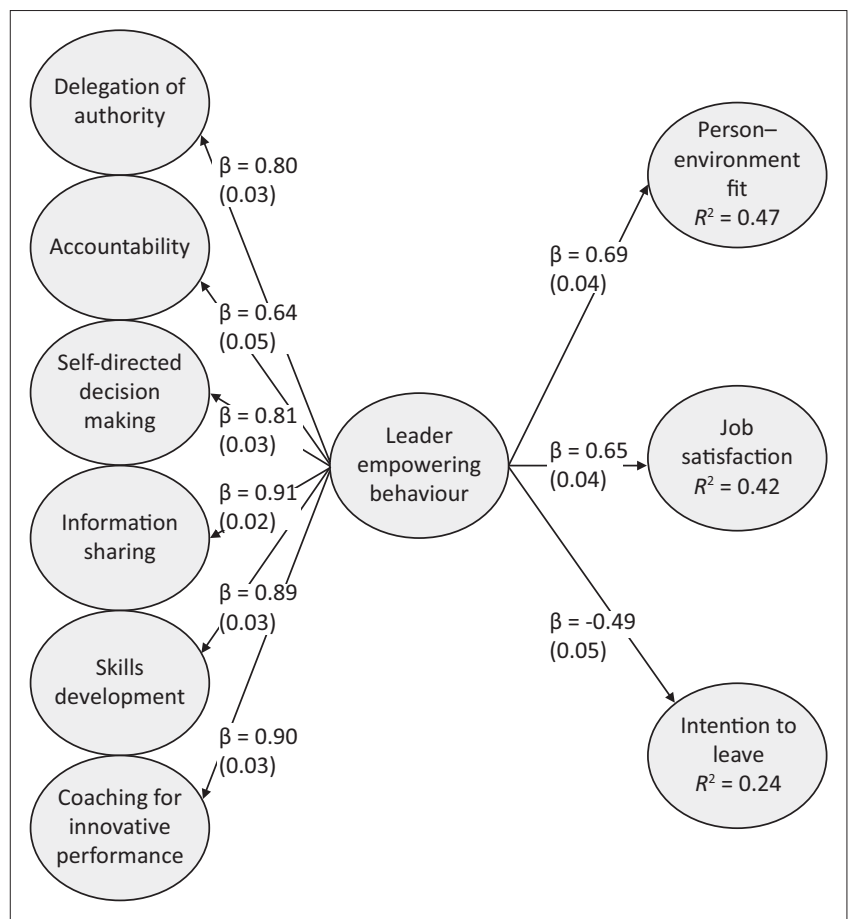

FIGURE 1: The hypothesised structural model (standard errors in parentheses).

$p \leq 0.01)$ was statistically significant and displayed the anticipated sign. Hypothesis 1 is therefore supported.

For the model portion focusing on job satisfaction, leader empowering behaviour's path coefficient $(\beta=0.65$; $p \leq$ 0.01) was statistically significant and displayed the anticipated sign. Hypothesis 2 is therefore supported.

For the model portion focusing on intention to leave, leader empowering behaviour's path coefficient $(\beta=-0.49$; $p \leq 0.01$ ) was statistically significant and displayed the anticipated sign. Hypothesis 3 is therefore supported.

Regarding effect sizes (Cohen, 1988), the model accounted for the following percentages of variance explained $\left(R^{2}\right)$ : person-environment fit $=47 \%$ (large effect), job satisfaction $=42 \%$ (large effect) and intention to leave $=$ $24 \%$ (medium effect).

\section{Discussion}

The aim of the study was to assess the associations leader empowering behaviour have with person-environment fit, job satisfaction and intention to leave. 
Results showed that leader empowering behaviour is positively associated with person-environment fit. When leaders provide empowerment, it ensures that employees are sufficiently equipped to handle the demands of their job, have their needs met and allow them to closely identify with their organisation. This concurs with previous findings (Cai et al., 2018) and also contributes to the scarce literature base that exists between leader empowering behaviour and person-environment fit.

Furthermore, results showed that leader empowering behaviour is positively associated with job satisfaction. When empowered, employees are able to experience an enhanced sense of enjoyment from their jobs. This concurs with previous findings (Amundsen \& Martinsen 2014; Kim et al., 2018; Konczak et al., 2000; Vecchio et al., 2010).

Results also showed that leader empowering behaviour is negatively associated with intention to leave. Empowered employees are less inclined to think about leaving their current job or organisation as it provides them with sufficient incentives to stay. In return, employees offer a sense of goodwill to their respective manager and employer. This concurs with previous findings (Bester et al., 2015; Kim et al., 2018; Van Schalkwyk et al., 2010) and the reciprocation principle of social exchange theory (Blau, 1964; Cropanzano \& Mitchell, 2005).

To conclude, when leaders share the right amount of power, information, decision-making authority and skills development opportunities with their employees; coach them well; and hold them accountable for controllable outcomes, it should enable them to establish a well-fitted, satisfied and committed workforce.

\section{Conclusion}

\section{Limitations}

The study had various limitations. As the study focused on a single retail organisation, one cannot generalise the findings to the larger retail industry or other contexts. Furthermore, this study measured person-environment fit in a static manner, despite contrary findings by previous studies (Boon \& Biron, 2016; De Beer, Rothmann, \& Mostert, 2016; Gabriel, Diefendorff, Chandler, Moran, \& Greguras, 2014; Van Vianen, 2018).

\section{Recommendations}

Leaders need to be in sync with what their employees want and adapt their leadership style accordingly. Some employees may want more coaching and authority, whilst others may instead want more accountability, as the amount of coaching and authority they currently receive is in line with what they prefer. Others might want less authority and decision-making power, as it exceeds the need they have for it. Although empowerment, in essence, has a positive connotation, research has shown that one should be cautious of the 'toomuch-of-a-good-thing' effect (Sharma \& Kirkman, 2015).
Accordingly, the diversity of employee preferences calls for balanced and informed leadership. When the right balance between under-empowerment and over-empowerment is achieved, leaders should bring out the best in their employees.

Future research may study the proposed relationships of this study in different contexts to enable generalisation of findings to a larger audience. This will simultaneously add to the thin literature base that exists regarding the relationship between person-environment fit and leader empowering behaviour. As various employee and environmental characteristics may change over time, it may also be worthwhile to assess the constructs from a daily diary level, weekly diary level or other longitudinal perspectives.

\section{Acknowledgements}

The authors would like to acknowledge the organisation that participated in the study.

\section{Competing interests}

The authors have declared that no competing interests exist.

\section{Authors' contributions}

K.R. coordinated the data collection process and conducted the data analysis. K.R., S.R. and E.B. made contributions regarding the conceptualisation of the article, as well as writing and editing.

\section{Funding information}

This research received no specific grant from any funding agency in the public, commercial or not-for-profit sectors.

\section{Data availability statement}

Only the primary researchers have access to the primary data as approved by the ethics committee.

\section{Disclaimer}

The views and opinions expressed in this article are those of the authors and do not necessarily reflect the official policy or position of any affiliated agency of the authors.

\section{References}

Ahearne, M., Mathieu, J., \& Rapp, A. (2005). To empower or not to empower your sales force? An empirical examination of the influence of leadership empowerment behavior on customer satisfaction and performance. Journal of Applied Psychology, 90(5), 945-955. https://doi.org/10.1037/0021-9010.90.5.945

Amundsen, S., \& Martinsen, Ø.L. (2014). Empowering leadership: Construct clarification, conceptualization, and validation of a new scale. The Leadership Quarterly, 25(3), 487-511. https://doi.org/10.1016/j.leaqua.2013.11.009

Anderson, H.J., Baur, J.E., Griffith, J.A., \& Buckley, M.R. (2017). What works for you may not work for (Gen) me: Limitations of present leadership theories for the new generation. The Leadership Quarterly, 28(1), 245-260. https://doi.org/10.1016/j. leaqua.2016.08.001

Arnold, J.A., Arad, S., Rhoades, J.A., \& Drasgow, F. (2000). The empowering leadership questionnaire: The construction and validation of a new scale for measuring leader behaviors. Journal of Organizational Behavior, 21(3), 249-269. https://doi. org/10.1002/(SICI)1099-1379(200005)21:3<249::AID-JOB10>3.0.CO;2-\# 
Bester, J., Stander, M.W., \& Van Zyl, L.E. (2015). Leadership empowering behaviour, psychological empowerment, organisational citizenship behaviours and turnover intention in a manufacturing division. SA Journal of Industrial Psychology, 41(1) 1-14. https://doi.org/10.4102/sajip.v41i1.1215

Blau, P.M. (1964). Exchange and power in social life. New York, NY: John Wiley.

Boon, C., \& Biron, M. (2016). Temporal issues in person - Organization fit, person - Job fit and turnover: The role of leader-member exchange. Human Relations, 69(12) 2177-2200. https://doi.org/10.1177/0018726716636945

Buckingham, M., \& Coffman, C. (1999). First, break all the rules: What the world's greatest managers do differently. New York, NY: Simon \& Schuster.

Cable, D.M., \& DeRue, D.S. (2002). The convergent and discriminant validity of subjective fit perceptions. Journal of Applied Psychology, 87(5), 875-884. https:// doi.org/10.1037/0021-9010.87.5.875

Cai, D., Cai, Y., Sun, Y., \& Ma, J. (2018). Linking empowering leadership and employee work engagement: The effects of person-job fit, person-group fit, and proactive personality. Frontiers in Psychology, 9(1), 1304. https://doi.org/10.3389/fpsyg. 2018.01304

Cheong, M., Yammarino, F.J., Dionne, S.D., Spain, S.M., \& Tsai, C.Y. (2019). A review of the effectiveness of empowering leadership. The Leadership Quarterly, 30(1), 34-58. https://doi.org/10.1016/j.leaqua.2018.08.005

Cohen, J. (1988). Statistical power analysis for the behavioral sciences (2nd edn.) Hillsdale, NJ: Lawrence Erlbaum Associates.

Cropanzano, R., \& Mitchell, M.S. (2005). Social exchange theory: An interdisciplinary review. Journal of Management, 31(6), 874-900. https://doi.org/10.1177/ 0149206305279602

De Beer, L.T., Rothmann Jr, S., \& Mostert, K. (2016). The bidirectional relationship between person-job fit and work engagement: A three-wave study. Journal of Personnel Psychology, 15(1), 4-14. https://doi.org/10.1027/1866-5888/a000143

Gabriel, A.S., Diefendorff, J.M., Chandler, M.M., Moran, C.M., \& Greguras, G.J. (2014). The dynamic relationships of work affect and job satisfaction with perceptions of fit. Personnel Psychology, 67(2), 389-420. https://doi. org/10.1111/peps.12042

Hellgren, J., Sjöberg, A., \& Sverke, M. (1997). Intention to quit: Effects of job satisfaction and job perceptions. In F. Avallone, J. Arnold \& K. De Witte (Eds.) Feelings work in Europe (pp. 415-423). Milano: Guerini.

Hom, P.W., \& Griffeth, R.W. (1991). Structural equations modeling test of a turnove theory: Cross-sectional and longitudinal analyses. Journal of Applied Psychology, 76(3), 350-366. https://doi.org/10.1037/0021-9010.76.3.350

IBM Corp. (2017). IBM SPSS Statistics for Windows, Version 25.0. Armonk, NY: IBM Corp.

Kiazad, K., Holtom, B.C., Hom, P.W., \& Newman, A. (2015). Job embeddedness: A multifoci theoretical extension. Journal of Applied Psychology, 100(3), 641-659. https://doi.org/10.1037/a0038919

Kim, M., Beehr, T.A., \& Prewett, M.S. (2018). Employee responses to empowering leadership: A meta-analysis. Journal of Leadership \& Organizational Studies, 25(3), 257-276. https://doi.org/10.1177/1548051817750538

Konczak, L.J., Stelly, D.J., \& Trusty, M.L. (2000). Defining and measuring empowerment leader behaviours: Development of an upward feedback instrument. Educational and Psychological Measurement, 60(2), 301-313. https://doi.org/10.1177/ 00131640021970420

Kristof-Brown, A.L., \& Guay, R.P. (2011). Person-environment fit. In S. Zedeck (Ed.) APA handbook of industrial and organizational psychology (pp. 3-50). Washington, DC: American Psychological Association.
Lee, S., Cheong, M., Kim, M., \& Yun, S. (2017). Never too much? The curvilinear relationship between empowering leadership and task performance. Group \& Organization Management, 42(1), 11-38. https://doi.org/10.1177/1059601116646474.

Lovelace, K.J., Manz, C.C., \& Alves, J.C. (2007). Work stress and leadership development: The role of self-leadership, shared leadership, physical fitness and flow in managing demands and increasing job control. Human Resource Management Review, 17(4), 374-387. https://doi.org/10.1016/j.hrmr.2007.08.001

Muthén, L.K., \& Muthén, B.O. (1998-2019). Mplus user's guide (8th edn.). Los Angeles, CA: Muthén \& Muthén.

Raykov, T. (2009). Interval estimation of revision effect on scale reliability via covariance structure modeling. Structural Equation Modeling, 16(3), 539-555. https://doi.org/10.1080/10705510903008337

Redelinghuys, K., \& Botha, E. (2016). Person-environment fit, job satisfaction and intentions to leave: The moderating effect of leader empowering behaviour Journal of Psychology in Africa, 26(1), 11-21. https://doi.org/10.1080/14330237. 2015.1101273

Redelinghuys, K., Rothmann, S., \& Botha, E. (2019a). Workplace flourishing: Measurement, antecedents and outcomes. SA Journal of Industrial Psychology, 45(0), a1549. https://doi.org/10.4102/sajip.v45i0.1549

Redelinghuys, K., Rothmann, S., \& Botha, E. (2019b). Flourishing-at-work: The role of positive organizational practices. Psychological Reports, 122(2) 609-631. https:// doi.org/10.1177/0033294118757935

Settoon, R.P., Bennett, N., \& Liden, R.C. (1996). Social exchange in organizations: Perceived organizational support, leader-member exchange, and employee reciprocity. Journal of Applied Psychology, 81(3), 219-227. https://doi.org/ reciprocity. Journal of Applied

Sharma, P.N., \& Kirkman, B.L. (2015). Leveraging leaders: A literature review and future lines of inquiry for empowering leadership research. Group \& Organization Management, 40(2), 193-237. https://doi.org/10.1177/1059601115574906

Sjöberg, A., \& Sverke, M. (2000). The interactive effect of job involvement and organizational commitment on job turnover revisited: A note on the mediating role of turnover intention. Scandinavian Journal of Psychology, 41(3), 247-252. https://doi.org/10.1111/1467-9450.00194

Smit, N.W., De Beer, L.T., \& Pienaar, J. (2016). Work stressors, job insecurity, union support, job satisfaction and safety outcomes within the iron ore mining environment. SA Journal of Human Resource Management, 14(1), a719. https:// doi.org/10.4102/sajhrm.v14i1.719

Spector, P.E. (1997). Job satisfaction: Application, assessment, causes, and consequences. Thousand Oaks, CA: Sage.

Taplin, I.M., \& Winterton, J. (2007). The importance of management style in labour retention. International Journal of Sociology and Social Policy, 27(1/2), 5-18. https://doi.org/10.1108/01443330710722724

Tuckey, M.R., Bakker, A.B., \& Dollard, M.F. (2012). Empowering leaders optimize working conditions for engagement: A multilevel study. Journal of Occupationa Health Psychology, 17(1), 15-27. https://doi.org/10.1037/a0025942

Van Schalkwyk, S., Du Toit, D.H., Bothma, A.S., \& Rothmann, S. (2010). Job insecurity, leadership empowerment behaviour, employee engagement and intention to leave in a petrochemical laboratory. SA Journal of Human Resource Management, 8(1), a234. https://doi.org/10.4102/sajhrm.v8i1.234

Van Vianen, A.E. (2018). Person-environment fit: A review of its basic tenets. Annual Review of Organizational Psychology and Organizational Behavior, 5(1), 75-101. https://doi.org/10.1146/annurev-orgpsych-032117-104702

Vecchio, R.P., Justin, J.E., \& Pearce, C.L. (2010). Empowering leadership: An examination of mediating mechanisms within a hierarchical structure. The Leadership Quarterly, 21(3), 530-542. https://doi.org/10.1016/j.leaqua.2010.03.0140 